\title{
Project CERITA - A Peacebuilding Initiative through Storytelling
}

\author{
Roosalina Wulandari \\ International Business, Binus Business School \\ Bina Nusantara University, Jakarta 11480, Indonesia \\ rwulandari@binus.edu
}

Received: September $9^{\text {th }}, 2019 /$ Accepted: September $29^{\text {th }}, 2019$

\begin{abstract}
The rising intolerance in Indonesia is spiking and has become more confounding due to the heated political temperature following series of recent national elections. Religious identity is politicized in a magnitude that escalates religious fundamentalism and consequently, intolerance. Past research shown how personal uncertainty enable individuals to find closure through firm beliefs and ideologies. This article is aimed to understand how religious intolerance function as a coping mechanism towards perceived threats of challenged worldviews, and how it potentially strengthened when supported collectively. The paper aim to focus on efforts made in the area of promotion of tolerance and inclusivity, understanding the complexity of identity helps peacebuilding initiatives to manage religious intolerance. The paper will then highlight Project CERITA (Community Empowerment for Raising Inclusivity and Trust through Technology Application), a peacebuilding program initiated by The Habibie Center that conducted storytelling and dialog facilitation workshop in six cities in Indonesia to promote peace and counter religious intolerance.
\end{abstract}

\section{INTRODUCTION}

Indonesia is currently exposed to a challenging virtue of rising intolerance. Scholars and observers of Indonesian politics agree that Indonesian Islam and society is moving progressively towards conservative direction (Hamayotsu, 2013). Despite the fact that the 1998 riot and the fall of the New Order regime opened doors to democracy (McCoy, 2013), the changing political nuance accommodates social vigilantism that promotes intolerance and discriminative behaviors (Menchik, 2014). This leads the situation to a heated religious group interaction between the Muslim majority groups and the other groups which creates concerns over the threat towards liberalism and religious pluralism (McCoy, 2013). The recent democratic exercises in Indonesia, began with the 2017 Jakarta's gubernatorial election and escalated throughout the 2019 Presidential's election, suffers from the rising intolerance ambience. Findings from a nation-wide survey conducted by CSIS (2017) revealed alarming results on level of intolerance towards differences of ideas, values and beliefs. The result displays resistance towards leadership of different religion that the Muslim majority. Echoing to the result is the survey conducted by PPIM-UIN [2017] also reflecting on factors contributing to the rising intolerance, such as perceived threats towards the Muslim majority. The phenomenon of intolerance is also amplified by the growing spirit of religious purification movements which accommodates factors of exclusions and eschewing any forms of innovation and engagement with cultural context.

The phenomenon of intolerance in Indonesia is explained by Menchik (2014) as a result of Godly Nationalism. A term that defines an imagined community united by common, orthodox theism, and collaboratively mobilized by the state with the support of existing religious organizations. While Godly Nationalism demands citizens' faith of God, no specific religion is enforced. Hence, Indonesia's develop a national identity of being exclusively religious but not particular. For this 
national identity to sustain, some beliefs must be privilege and any forms of deviations is not tolerated as it is perceived as threats to the preferred worldview, particularly religion.

\section{Religious Intolerance}

Recent development recognized five different facets that have characterized much of intergroup contact research over the past 20 years [Dovidio, Love, Schellhaas, \& Hewstone, 2017]. Those facets are forms of contact, mediating mechanisms, moderating factors, nature and temporal stage of the intergroup exchange, and outcomes of contact. Contemporary research in forms of contact specify types of contact into direct [extended and vicarious] and indirect [imagined and virtual] contact. As stated by Pettigrew and Tropp [2006] and Brown and Hewstone [2005], intergroup contact helps increase empathy with the outgroup and reduce anxiety

According to Integrated Threat Theory [ITT] perspective, intergroup anxiety is displayed as high when people rely on their response on cognitive heuristics, namely stereotypes, and in return expressing typically negative emotions and evaluations, such as prejudice [Stephan, Stephan, \& Gudykunst, 1999]. Since ITT focuses on prejudice, its ability to predict intergroup attitude is highlighting mostly on the detrimental effects of intergroup relations as induced by anxiety. As anxiety is claimed to be one of the major threats that leads to anxiety, ITT also incorporates uncertainty as a related construct that heightened prejudice.

Another perspective that is also focusing immensely on uncertainty would be coming from Uncertainty-Identity Theory [Hogg, 2007]. The key premise stated that since uncertainty creates difficulties to anticipate and plan, it empowers motives and behavior to reduce it [Hogg, 2000, 2007a, 2012]. In the light of promoting intolerance, Hogg and Adelman [2013] argued that self-uncertainty promotes individuals to incline with extreme groups. This could be the risk factors following predictions of the Uncertainty-Identity Theory that identified how people, in effort to reduce anxiety, have the tendency to be self-inclusively categorizing themselves into groups when faced with uncertainties, and would prefer groups that display clear, simple, unambiguous, consensual, and focused - which is prototypically relevant with groups holding extreme ideologies. The logic of relationship between uncertainty and group entitativity was found across studies explaining radicalism and zealotry (Hogg, 2005, 2007; Hogg, Adelman, \& Blagg, 2010; Kruglanski, Pierro, Mannetti, \& De Grada, 2006).

\section{Project CERITA - A Peacebuilding Initiative}

Project CERITA (Community Empowerment for Raising Inclusivity and Trust through Technology Application) is a peacebuilding initiative, established in 2017 by The Habibie Center, to counter intolerance. As a peacebuilding initiative, Project CERITA is using the social psychology approach in identifying and analyzing how social identity shift through an exposure with diverse culture while developing constructive storytelling as a tool to initiate peacebuilding efforts collectively. From a practical perspective, it aims to understand how constructive storytelling could bridge communication to find common grounds and shared social identity in the communities.
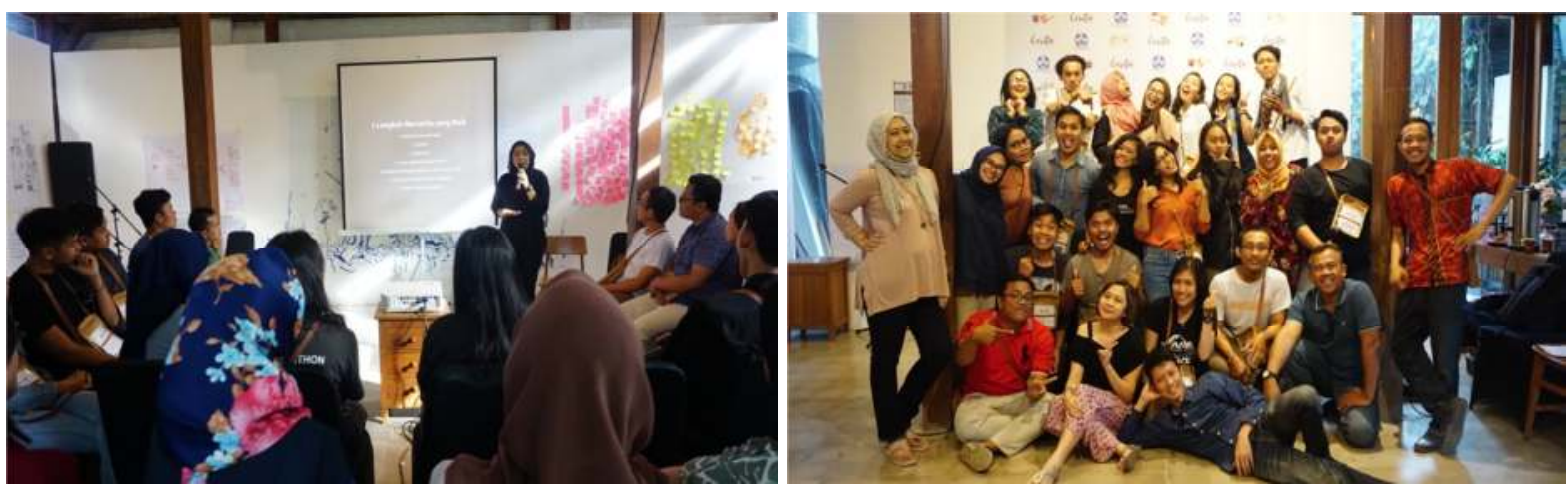

Project CERITA Bali - August 2-3, 2019 
Project CERITA was established with three elements, Kafe CERITA, Duta CERITA, and Peta CERITA. Kafe CERITA is the core program that implement storytelling and dialogue facilitation workshops for the Duta CERITAs. Duta (Ambassador) CERITAs are the youth influencer carefully selected to be launched as the champion of peace to promote tolerance and inclusivity through storytelling and dialogues. Once they graduated from the program, they are to carry the mandate of expanding their knowledge and network in their own communities, spreading the message of peace. These expansions are to be mapped in Peta CERITA, an online platform for the stories shared, to make the program accessible for anyone who wants to understand peace messages better and help promote peace in general.

Storytelling is used as main communication tools to start a peace dialogue. In many conflict contexts, storytelling is widely used in early education phase where children are being introduced to an alternative reality [than the conflicted one] while integrating peace values of finding shared reality instead of highlighting differences that is keeping groups segregated (Senehi, 2002; Chongruksa, Prinyapol, Wadeng, \& Padungpong, 2010; Milojević \& Izgarjan, 2014). Indonesia is currently not in a somewhat conflict context yet, but the potential is there. Hence, preventive measures are needed to ensure the preservation of the cultural diversity as the nation's identity. Engaging hundreds of youth in six cities in Java and Bali, the peacebuilding initiative included all existing beliefs in Indonesia aimed to establish positive contact and exposure between groups.

\section{PROBLEM STATEMENT}

As the level of intolerance in Indonesia has reached an alarming level, it is imperative to identify how intolerance can be managed and countered by promotion of tolerance and inclusivity.

\section{THE METHOD}

This research employed qualitative method by reviewing the existing peacebuilding initiatives namely Project CERITA initiated by The Habibie Center and was conducted in six cities in Indonesia. The research involved observatory participation in which the researcher was directly involved in the program itself as one of the facilitators.

\section{RESULTS AND DISCUSSIONS}

Storytelling has been widely used to promote peace as it creates engagement in a non-threatening and non-intimidating ways (Senehi, 2002; Chongruksa, Prinyapol, Wadeng, \& Padungpong, 2010). In addition to that, many cultures have embodied storytelling as a way to transfer values to the younger generations. As for the conflict contexts, storytelling is a powerful tool to introduce an alternative reality to counter prejudice and stereotype (Milojević \& Izgarjan, 2014).

In the concerns of rising intolerance in Indonesia, peacebuilding initiatives are emerging to promote inclusivity and shared values. Initiatives like Project CERITA is a notable example of how peacebuilding initiatives can play parts in the context of countering intolerance. As a peacebuilding initiative, Project CERITA aims to create contact in effort to lessen perceived threats [Stephen, Stephen \& Gudykunst, 1999] amongst existing religious groups in Indonesia. After six cities roadshow, Project CERITA successfully recruited 30 youth influencers in each city that was trained to conduct dialog facilitation and storytelling to initiate peaceful contact.

\section{CONCLUSION}

The search for meaning has always been paramount to human's existential quest. Various paths are being undertaken in that quest and some paths are more exclusive than others. Some find solace through the paths of religion. However, those exclusive paths come with a consequence of creating a shared belief that theirs is better than others and thus, the right one. When belief is overvalued positively, superiority and intolerance are prone to happen.

Countering intolerance means promoting inclusivity. One of the ways that can be done to promote tolerance and inclusivity is through exposure to other group members, such as through interfaith dialogue. As a melting pot, schools and universities can take part to host and accommodate a safe 
space for dialogues to happen. Interfaith dialogue offers access to be exposed and get into contact with people from different groups, and hopefully encourage positive interactions to search for common grounds.

\section{REFERENCES}

Ada apa dengan milenial? Orientasi sosial, ekonomi dan politik. (Center for Strategic and International Studies, 2017)

Brown, R., \& Hewstone, M. (2005). An integrative theory of intergroup contact. Advances in experimental social psychology, 37(37), 255-343.

Chongruksa, D., Prinyapol, P., Wadeng, Y., \& Padungpong, C. (2010). Storytelling: program for multicultural understanding and respect among Thai-Buddhist and Thai-Muslim students. Procedia-Social and Behavioral Sciences, 5, 282-288.

Dovidio, J. F., Love, A., Schellhaas, F. M., \& Hewstone, M. (2017). Reducing intergroup bias through intergroup contact: Twenty years of progress and future directions. Group Processes \& Intergroup Relations, 20(5), 606-620.

Hamayotsu, K. (2013). The Limits of Civil Society in Democratic Indonesia: Media Freedom and Religious Intolerance. Journal of Contemporary Asia,43(4), 658-677.

Hogg, M. A. (2000). Subjective uncertainty reduction through self-categorization: A motivational theory of social identity processes. European review of social psychology, 11(1), 223-255.

Hogg, M. A. (2005). Uncertainty, social identity, and ideology. In Social identification in groups (pp. 203-229). Emerald Group Publishing Limited.

Hogg, M. A. (2007). Uncertainty-identity theory. Advances in experimental social psychology, 39, 69-126.

Hogg, M. A., \& Adelman, J. (2013). Uncertainty-identity theory: Extreme groups, radical behavior, and authoritarian leadership. Journal of Social Issues, 69(3), 436-454.

Hogg, M. A., Adelman, J. R., \& Blagg, R. D. (2010). Religion in the face of uncertainty: An account of religiousness. Personality and Social Psychology Review, 14(1), 72-83.

Kruglanski, A. W., Pierro, A., Mannetti, L., \& De Grada, E. (2006). Groups as epistemic providers: need for closure and the unfolding of group-centrism. Psychological review, 113(1), 84.

McCoy, M. E. (2013). Purifying Islam in Post-Authoritarian Indonesia: Corporatist Metaphors and the Rise of Religious Intolerance. Rhetoric and Public Affairs,16(2), 275.

Menchik, J. (2014). Productive Intolerance: Godly Nationalism in Indonesia. Comparative Studies in Society and History,56(03), 591-621.

Milojević, I., \& Izgarjan, A. (2014). Creating alternative futures through storytelling: A case study from Serbia. Futures, 57, 51-61.

Pettigrew, T. F., \& Tropp, L. R. (2006). A meta-analytic test of intergroup contact theory. Journal of personality and social psychology, 90(5), 751. 
PPIM, U. Jakarta. 2017. Api dalam Sekam: KeberAGAMAan Gen Z-Survei Nasional tentang Sikap Keberagamaan di Sekolah dan Universitas di Indonesia.

Senehi, J. (2002). Constructive storytelling: A peace process. Peace and Conflict Studies, 9(2), 41-63.

Stephan, W. G., Stephan, C. W., \& Gudykunst, W. B. (1999). Anxiety in intergroup relations: A comparison of anxiety/uncertainty management theory and integrated threat theory. International Journal of Intercultural Relations, 23(4), 613-628. 